\title{
UCI Libraries Celebrate UCI
}

Each April, the University of California, Irvine (UCI), throws a huge open houseCelebrate UCI - for students, faculty, staff, prospective students and their parents, and the community. The UCI Libraries have been an integral part of this event for almost 20 years.

Through tours of the libraries, demonstrations of computerized library systems, a book sale, and an information booth prominently situated amongst those representing a diverse cross section

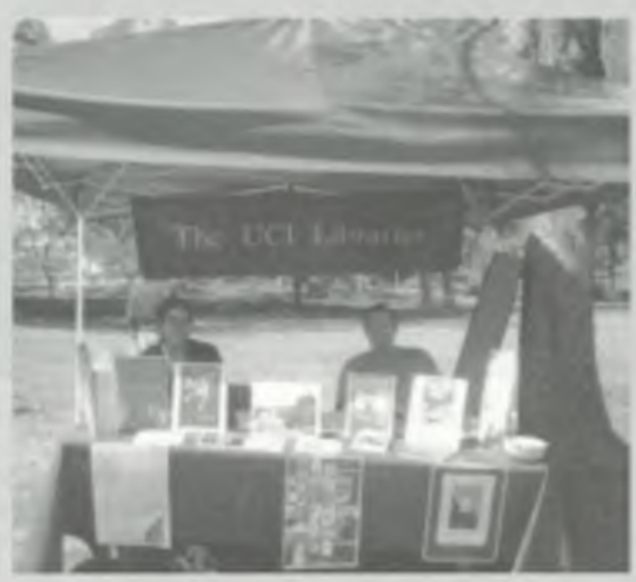

With a bright new banner to attract attention to their exhibit, library staff are ready to greet the next visitor.

enger hunt designed to direct visitors to the Main and Science Libraries where they could then take a tour of the facilities. Library staff from every division and from across all job classifications devoted part of their weekend to ensure that the library was well represented at this important community-building event.

As both the campus and the libraries dedicate increased resources to outreach efforts in local schools, parof student groups and university services, the UCI Libraries reaches out to the community on campus and beyond.

In fact, a simple low-tech solution, a new bright blue and gold banner (UCI's colors) enhanced our visibility and drew visitors to our booth. This year, in addition to highlighting library publications and information about collections, services, and exhibits, library staff created a scav-

a new name, format, and editorial focus by its editors. The new journal, called $R B M$ : $A$ Joumal of Rare Books, Manuscripts, and Cultural Heritage, will feature a larger format and will expand its focus to include stewards of special collections outside the library world.

Editors Lisa Browar and Marvin J. Taylor explained the reasons behind the changes: "As rare book and manuscripts libraries have previously metamorphosed into special collections libraries, so too are special collections libraries changing into cultural heritage repositories before our eyes." $R B M$ will reflect these changes, appealing to an audience not only of librarians, but also of ". . . scholars, students, archivists, fine printers, photographers, museum professionals, video producers, filmmakers, and anyone interested

\section{Stop by the ACRL booth and win!}

Stop by ACRL's booth number 3344 at the ALA Annual Conference in Chicago, July 6-11. Find out more about ACRL's National Conference in Denver, March 15-18, 2001, and enter a drawing to win prizes!

Representatives from the Denver Metro Convention \& Visitors Bureau will be on hand to answer your questions about Denver and its attractions. The bureau has donated a number of items that $\mathrm{ACRL}$ will be raffling off, such as desktop clocks, mugs, Denver wildflower books, toiletry bags, and a Denver organizer.

So visit ACRL this summer, learn more about its activities and conferences, and one of these prizes could be yours! 